\title{
ANALISIS MAKANAN ALAMI DALAM LAMBUNG DAN MIKROHABITAT LOBSTER PASIR (Panulirus homarus) FASE PUERULUS DI TELUK AWANG
}

\author{
Muhsinul Ihsan*\#, Suhirman*), Edi M. Jayadi*), Reza Sagista*), Yuli Eka Hardianti*), Wahyu Bintang Ilahi*), \\ Handa Muliasari**, dan Lalu Achmad Tantilar Wangsajati Sukmaring Kalih***) \\ *) Program Studi Tadris IPA Biologi, Fakultas Tarbiyah dan Keguruan, Universitas Islam Negeri Mataram \\ J. Gajah Mada No. 100, Jempong, Mataram \\ *) Program Studi Farmasi, Universitas Mataram \\ Jl. Majapahit No.62, Gomong, Kec. Selaparang, Kota Mataram, Nusa Tenggara Bar. 83126 \\ **) Program Studi Pemanfaatan Sumberdaya Perikanan, Universitas 45 Mataram \\ Jl. Imam Bonjol Cakranegara Utara - Mataram
}

(Naskah diterima: 24 Juni 2019; Revisi final: 13 September 2019; Disetujui publikasi: 13 September 2019)

\begin{abstract}
ABSTRAK
Pulau Lombok memiliki potensi dalam industrialisasi lobster. Aspek makanan alami larva perlu dipahami untuk mendukung pembenihan lobster. Tujuan penelitian ini untuk menganalisis makanan alami dalam lambung dan mikrohabitat lobster pasir (Panulirus homarus) fase Puerulus. Cairan lambung dari sepuluh ekor Puerulus dianalisis dengan metode analisis plankton. Makanan alami di mikrohabitat dikoleksi dengan menyaring seratus liter air laut dari alat tangkap dengan jaring plankton. Makanan alami dalam lambung meliputi fitoplankton dan zooplankton. Fitoplankton terdiri atas satu kelas yaitu bacillariophyceae, tiga ordo yaitu rhabdonematales; naviculales; fragilariales; dan tiga spesies yaitu: Grammatophora marina, Navicula cancellata, dan Synedra radians. Zooplankton terdiri atas kelas oligothriceae ordo choreotrichi spesies Tintinnopsis lobiancoi. Makanan alami di mikrohabitat juga terdiri atas fitoplankton dan zooplankton. Struktur komunitas fitoplankton terdiri atas enam kelas; 26 ordo; dan 39 spesies, sedangkan komunitas zooplankton terdiri atas 10 kelas; 10 ordo; dan 20 spesies. Indeks keanekaragaman makanan alami dalam lambung sebesar 1,39. Rata-rata nilai kelimpahan, indeks keanekaragaman, keseragaman, dan dominansi fitoplankton, serta zooplankton di mikrohabitat berturut-turut 65.744 sel/50 mL; 3,03; 0,82; 0,08; serta 182 sel/50 mL; 1,89; 0,62; 0,3. Grammatophora marina, Navicula cancellata, Synedra radians, dan Tintinnopsis lobiancoi berpotensi sebagai pakan alami larva lobster pasir (Panulirus homarus).
\end{abstract}

KATA KUNCl: Iobster pasir; puerulus; fitoplankton; zooplankton; makanan alami

ABSTRACT: Analysis of natural diet in stomach and microhabitat of puerulus spiny lobster (Panulirus homarus) in Awang Bay. By: Muhsinul Ihsan, Suhirman, Edi M. Jayadi, Reza Sagista, Yuli Eka Hardianti, Wahyu Bintang Ilahi, Handa Muliasari, and Lalu Achmad Tantilar Wangsajati Sukmaring Kalih

Lombok Island has a high potential to be developed as a central area for lobster farming industry due to the abundance of puerulus in thearea. One of the requirements to support the industry is by providing the biological aspect information of spiny lobster (Panulirus homarus) especially its local natural diet during the puerulus phase, which is required to develop a sustainable operation of lobster hatchery. This research was aimed to determine the natural diet in the stomach and microhabitat of puerulus of spiny lobster. The natural diet in the stomach fluid of ten Puerulus was determined using plankton analysis method, while the natural diet in thelobster microhabitat was collected by filtering one hundred liters of seawater in the catching media by using plankton nets. The natural diet in thestomach of puelurus includes phytoplankton and zooplankton. Phytoplankton consisted of one class, bacillariophyceae; three ordines, rhabdonematales, naviculales, fragilariales; and three species, Grammatophora marina, Navicula cancellata, and Synedra radians. Zooplankton consisted of species Tintinnopsis lobiancoi . The natural diet in the microhabitat also consisted of phytoplankton and zooplankton. The community structure of phytoplankton consisted of six classes; 26

\footnotetext{
\# Korespondensi: Program Studi Tadris IPA Biologi, Fakultas

Tarbiyah dan Keguruan, Universitas Islam Negeri Mataram.

Jl. Gajah Mada No. 100, Jempong, Mataram, Indonesia.

Tel. + 62818540065

E-mail: ihsan@ uinmataram.ac.id
} 
ordines; and 39 species, while zooplankton consisted of 10 classes; 10 ordines; and 20 species. The diversity index of the natural diet in the puerulus stomach was classified as moderate $H^{\prime}$ 1.39. The averages of abundance, diversity, similarity, and dominance index of phytoplankton and zooplankton in the microhabitat were 65,744 cell/50 mL; $3.03 ; 0.82 ; 0.08$; and 182 cell/50 mL; 1.89; $0.62 ; 0.3$ respectively. Grammatophora marina, Navicula cancellata, Synedra radians, and Tintinnopsis lobiancoi were found to be dominant and have the potential to be developed as the natural hatchery diet for spiny lobster larvae.

\section{KEYW ORDS Spiny lobster; puerulus; phytoplankton; zooplankton; natural diet}

\section{PENDAHULUAN}

Pulau Lombok memiliki potensi dalam pengembangan industrialisasi lobster. Hal ini didukung oleh ketersediaan benih lobster di alam yang melimpah. Berdasarkan data sensus dalam kurun waktu 2007-2014, Pulau Lombok menjadi sumber benih lobster terbesar di Indonesia. Pada tahun 2009, jumlah benih lobster yang berhasil disensus mencapai 600.000 ekor, dengan jumlah yang paling dominan adalah lobster pasir (Panulirus homarus L.). Musim puncak keberadaan benih Lobster Pasir (P. homarus) terjadi pada bulan Juli, sedangkan waktu pemijahan diprediksi terjadi pada bulan Desember (Bahrawi et al., 2014). Eksplorasi benih lobster di alam secara berlebihan dikhawatirkan mengancam populasi lobster. Berdasarkan hal tersebut, Menteri Kementerian Kelautan dan Perikanan telah mengeluarkan Peraturan Menteri Nomor 56/Permen-KP/2016 tentang larangan penangkapan dan/atau pengeluaran lobster (Panulirus spp.) dalam rangka memulihkan populasi lobster di alam.

Industri pembenihan lobster harus dilakukan supaya populasi benih di alam tidak terganggu dan ketergantungan benih dari alam dapat dikurangi. Aspek biologi yang harus diketahui dalam pembenihan lobster adalah aspek makanan alami dan aktivitas predasi lobster pada fase larva dan postlarva di alam (Jeffs, 2007). Fase larva terdiri atas stadium filosoma, sedangkan postlarva (benih) terdiri atas stadium puerulus dan juvenil. Makanan alami larva Larva crustacea termasuk lobster adalah fitoplankton atau gabungan fitoplankton dan zooplankton (Jones, 1997).

Beberapa peneliti telah mengeksplorasi plankton sebagai makanan alami bagi larva lobster. Suzuki et al. (2006) menyatakan larva lobster (filosoma) bersifat opportunistic predator yaitu kelompok hewan dengan variasi mangsa yang luas. Larva lobster pada stadia filosoma memangsa berbagai crustacea seperti shrimps, copepod, dan amphipod. Ekstraksi materi genetik dari hepatopankreas menunjukkan bahwa filosoma memangsa cnidaria dan urochordata. Filosoma pada perkembangan tahap akhir memiliki ciri-ciri morfologi: pleopod memanjang, rami internal dan eksternal memiliki setae, tunas insang mulai muncul di bagian tengah sepanjang coxa pada pereiopod 1-4, maxilliped yang ketiga bifida, terbentuk spatula pada ujung terminal antennae, pigmentasi antenna pada bagian ujung dan tengah (Smith et al., 2009). Jeffs (2007) menyatakan bahwa aplikasi teknik PCR menemukan bahwa filosoma memangsa radiolaria, thaliacea, actinopterigii, hydrozoa, dan sagittoidea. Makanan utama filosoma adalah plankton khususnya Gelatinous zooplankton yang memiliki tubuh halus.

Trijoko \& Pasaribu (2004) meneliti komunitas zooplankton sebagai makanan alami larva lobster di Teluk Wedi Ombo, Gunung Kidul, Yogyakarta. Hasil penelitian tersebut menunjukkan bahwa komunitas zooplankton di Teluk Wedi Ombo terdiri atas delapan subkelas dan 24 genus. Berdasarkan kemelimpahan dan ukuran bukaan mulut larva lobster, Calanus dan Brachionus diduga menjadi kandidat yang sesuai sebagai makanan alami larva lobster.

Eksplorasi makanan alami lobster pasir (Panulirus homarus) fase puerulus di Teluk Awang, Lombok Tengah belum pernah dilakukan. Penelitian makanan alami lobster pasir (Panulirus homarus) di Teluk Awang yang telah dilakukan hanya pada fase juvenil awal (Ihsan et al., 2016). Perbedaan kondisi fisika dan kimiawi Teluk Awang dengan tempat-tempat yang lain diduga akan menyebabkan variasi makanan alami. Jumlah dan spesies plankton sebagai makanan alami larva lobster sangat dipengaruhi oleh kondisi fisik dan kimia perairan. Kondisi fisika meliputi suhu; tingkat kecerahan; intensitas cahaya matahari; dan kedalaman. Sedangkan kondisi kimiawi meliputi oksigen terlarut; karbondioksida; dan salinitas (Hartoko, 2013). Penelitian ini bertujuan untuk menganalisis makanan alami dalam lambung dan mikrohabitat lobster pasir (Panulirus homarus) fase puerulus di Teluk Awang, Lombok Tengah. Informasi makanan alami yang didapatkan diharapkan bermanfaat pada saat pemilihan dan kultur plankton sebagai makanan alami larva lobster pada kegiatan pembenihan lobster di masa yang akan datang.

\section{BAHAN DAN METODE}

\section{Lokasi Sampling}

Lokasi penelitian ini adalah di perairan Teluk Awang, Kecamatan Pujut, Kabupaten Lombok Tengah, 
Nusa Tenggara Barat (8 $872853 \mathrm{~S} 116^{\circ} 402333 \mathrm{E}$ ). Pemilihan lokasi didasarkan pada potensi benih lobster yang sangat besar di daerah ini (Bahrawi et al., 2014). Sampling dilakukan sebanyak enam kali di enam titik pada bulan Juni-Agustus 2017. Jarak titik sampling dengan daratan berkisar antara 291,3-1.259 m (Gambar 1). Bulan Juni-Agustus adalah masa puncak kelimpahan benih di Teluk Awang sehingga sampling di bulan-bulan ini diduga dapat mewakili bulan-bulan yang lain.

\section{Analisis Makanan Alami dalam Lambung}

Terdapat sepuluh ekor lobster pasir (Panulirus homarus) fase puerulus yang berhasil dikoleksi dari alat tangkap (pocongan). Lobster yang tertangkap termasuk dalam stadia postlarva yang belum mengalami pigmentasi (non pigmented puerulli). Sepuluh ekor lobster pasir (Panulirus homarus) fase puerulus dimasukkan dalam botol sampel yang berisi campuran $50 \mathrm{~mL}$ air laut dan $6 \mathrm{~mL}$ formalin 37\% Isolasi lambung dilakukan dengan pembedahan bagian cephalothorax. Lambung bagian kardiak berada setelah esophagus, sedangkan bagian pilorik sebelum saluran/duktus primer hepatopankreas (Ihsan et al., 2017). Cairan dalam lambung lo bster diambil dan diteteskan sebanyak $0,5 \mathrm{~mL}$ di atas kaca benda. Identifikasi makanan alami berupa plankton dilakukan dengan mikroskop binokuler pada perbesaran 400-1.000x. Identifikasi dilakukan sampai tingkat genus dan spesies menggunakan buku panduan identifikasi plankton laut (Lenz, 2000; Tomas, 1997; Yamaji, 1976).

\section{Analisis Makanan Alami di Mikrohabitat}

Metode sampling makanan alami di mikrohabitat dilakukan dengan teknik sampling plankton yang didasarkan pada meto de analisis sampel plankton oleh Hasanah et al. (2014); Putri \& Sari (2015); Kamariah \& Tarunamulia (2016). Mikrohabitat lobster pasir (Panulirus homarus) fase puerulus adalah alat tangkap, tempat menempelnya puerulus. Koleksi makanan alami dilakukan di dua tempat yaitu air sekitar alat tangkap (pocongan) dan air hasil rendaman alat tangkap (pocongan). Seratus liter air di sekitar alat tangkap (pocongan) diambil dan disaring dengan jaring plankton. Tiga ratus alat tangkap (pocongan) direndam dalam $100 \mathrm{~L}$ air laut. Air hasil rendaman disaring dengan jaring plankton. Jaring plankton yang digunakan berdimensi panjang $30 \mathrm{~cm}$; diameter $15 \mathrm{~cm}$; dan ukuran lubang $20,08 \mu \mathrm{m} / \mathrm{mesh}$ size 625 . Air hasil saringan dikoleksi dengan botol kolektor bervolume $50 \mathrm{~mL}$. Air dalam botol kolektor dipindahkan ke botol sampel yang berisi $6 \mathrm{~mL}$ formalin 37\% Identifikasi makanan alami dilakukan pada perbesaran 400-1.000x menggunakan buku panduan identifikasi plankton laut (Lenz, 2000; Tomas, 1997; Yamaji, 1976). Identifikasi dilakukan sampai tingkat genus dan spesies.

\section{Analisis Data}

Setiap spesies yang ditemukan dicatat jumlahnya kemudian dilakukan analisis kelimpahan (K), keanekaragaman $\left(\mathrm{H}^{\prime}\right)$, keseragaman $(\mathrm{E})$, dan indeks dominansi (C). Rumus-rumus yang digunakan sebagai berikut:
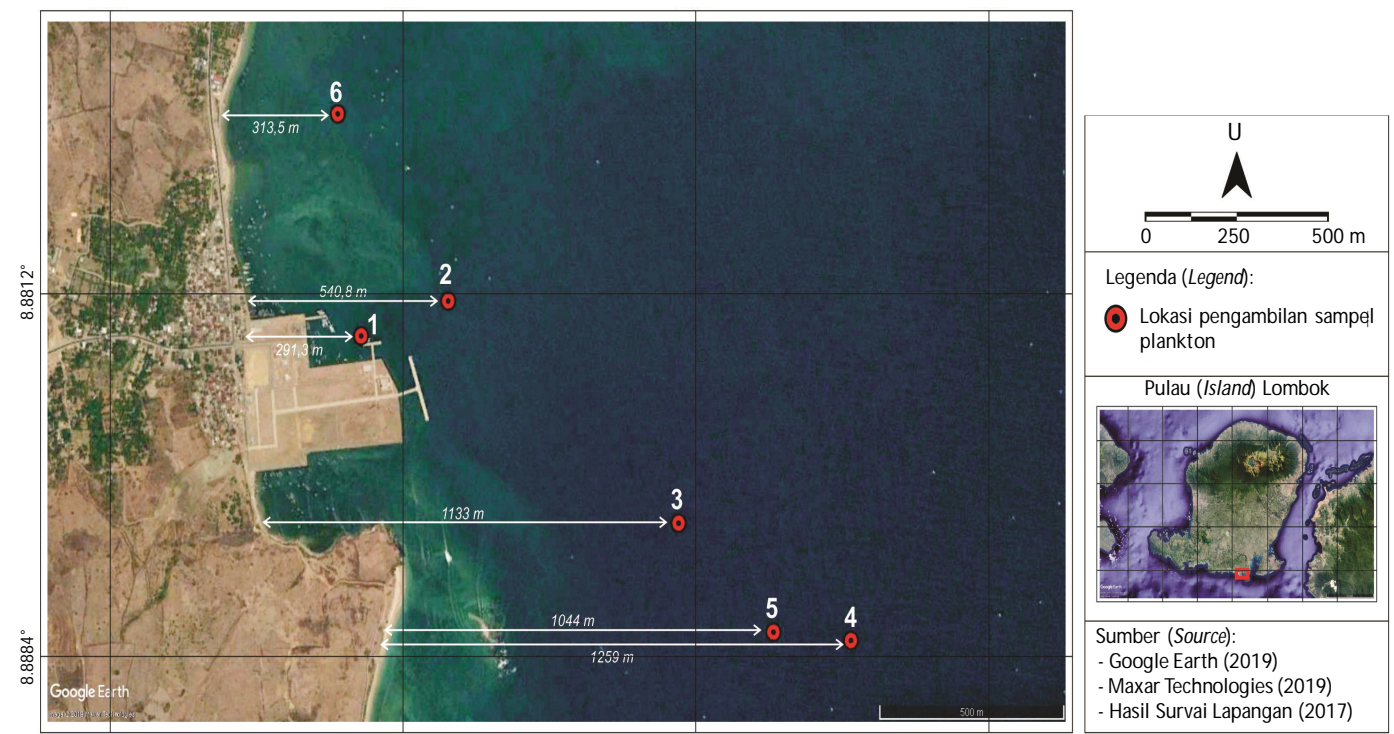

Gambar 1. Lokasi sampling (modifikasi citra google earth, 2019).

Figure 1. Location of sampling in Awang Bay (modification citra google earth, 2019). 
Kelimpahan

di mana:

$$
\mathrm{N}=\mathrm{n} \times\left(\frac{\mathrm{V}_{\mathrm{r}}}{\mathrm{V}_{0}}\right) \times\left(\frac{1}{\mathrm{~V}_{\mathrm{s}}}\right)
$$

$\mathrm{N}=$ jumlah sel per liter

$\mathrm{N}=$ jumlah sel yang diamati

$v_{r}=$ volume sampel

$V_{0}=$ volume air yang diamati $(\mathrm{mL})$

$\mathrm{V}_{\mathrm{s}}=$ volume air yang tersaring (Fachrul, 2007)

Keanekaragaman

$$
\begin{aligned}
& H^{\prime}=-\sum P i \ln P i \\
& P i=\frac{n_{i}}{N}
\end{aligned}
$$

di mana:

$\mathrm{Pi}=$ kelimpahan relatif

$\mathrm{H}^{\prime}=$ indeks keanekaragaman Shanon

$\mathrm{n}_{\mathrm{i}}=$ jumlah individu jenis ke-1

$N=$ jumlah total semua jenis dalam komunitas

dengan kriteria jika:

$\mathrm{H}^{\prime} \leq 1 \quad$ : tingkat keanekaragaman rendah

$1<\mathrm{H}^{\prime} \leq 3$ : tingkat keanekaragaman sedang

$\mathrm{H}^{\prime}>3$ : tingkat keanekaragaman tinggi (Magurran, 2004; Fachrul, 2007)

\section{Keseragaman}

di mana:

$$
E=\frac{H^{\prime}}{\operatorname{LnS}}
$$

$\mathrm{E}=$ indeks evenes/keseragaman

$\mathrm{H}^{\prime}=$ indeks keanekaragaman

$\mathrm{S}=$ jumlah total spesies

dengan kriteria jika:

$E>0,6$ : keseragaman jenis tinggi

$0,4 \leq \mathrm{E} \leq 0,6$ : keseragaman jenis sedang

$\mathrm{E}<0,4 \quad$ : keseragaman jenis rendah (Fachrul, 2007)

Dominansi

$$
\mathrm{d}=\frac{\mathrm{Nmax}}{\mathrm{N}}
$$

di mana:

$\mathrm{d} \quad=$ indeks dominansi

Nmax' = jumlah individu pada spesies yang paling melimpah

$\mathrm{N} \quad=$ jumlah total individu (Berger \& Parker, 1970)

dengan kriteria jika:

$0<\mathrm{C} f 0,5$ : tidak ada genus yang mendominasi

$0,5<\mathrm{C}<1$ : terdapat genus yang mendominasi

\section{HASIL DAN BAHASAN}

\section{Makanan Alami dalam Lambung Lobster Pasir (Panulirus homarus) Fase Puerulus}

Makanan alami yang ditemukan dalam lambung lobster pasir (Panulirus homarus) fase puerulus terdiri atas dua kelompok yaitu fitoplankton dan zooplankton. Terdapat empat spesies plankton dalam lambung dengan jumlah masing-masing spesies rata-rata satu ekor. Berdasarkan nilai standar deviasi dapat diketahui bahwa tidak semua lambung lobster yang teramati mengandung fitoplankton dan zooplankton (Tabel 1). Indeks keanekaragaman makanan alami dalam lambung tergolong sedang $\left(H^{\prime}=1,39\right)$.

Grammatophora marina (Lyngbye) Kützing, Navicula cancellata Donkin, dan Synedra radians Kützing termasuk dalam kelompok diatom. Kelompok ini memiliki dinding sel bersilika yang disebut frustula. Diatom merupakan produsen primer yang melimpah pada musim hujan. Sebagian besar diatom berkoloni dan membentuk fase sel istirahat (resting stage cells) ketika kondisi lingkungan kurang sesuai seperti konsentrasi nitrogen yang rendah dan intensitas cahaya yang kurang (Tsukazaki et al., 2013; Kuwata \& Jewson, 2015).

Spesies zooplankton yang ditemukan dalam lambung lobster pasir (Panulirus homarus) fase puerulus di Teluk Awang berbeda dengan spesies zooplankton yang ditemukan di dalam lambung lobster Jasus edwardsii fase filosoma di New Zealand. Gelatinous zooplankton (Siphonopora dan Ctenophora) teridentifikasi di dalam lambung J. edwardsii (O'rorke et al., 2013). Pada penelitian Conel et al. (2014) menemukan bahwa filosoma lobster bersifat opportunistic predator yang memangsa berbagai taksa zooplankton seperti Gadiforme, Cnidaria, Gastropoda, dan Crustacea. Pada penelitian ini hanya ditemukan Tintinnopsis lobiancoi Daday yang termasuk ke dalam protozooplankton. Perbedaan ini diduga disebabkan karena perbedaan kondisi habitat. Berdasarkan informasi dari penyelam dan nelayan yang diwawancarai, serta sampling tanah dari dasar perairan, dapat diketahui bahwa dasar perairan Teluk Awang berupa lumpur hitam. Kondisi ini berbeda dengan kondisi dasar perairan di New Zealand yang berupa daerah terumbu karang dan tidak ada lumpur hitam.

Tingkat keanekaragaman makanan alami yang ditemukan tergolong sedang. Hal ini diduga karena lobster pasir (Panulirus homarus) pada fase puerulus tidak melakukan aktivitas predasi dan aktivitas makan. Pada fase postlarva ini, puerulus bisa bertahan hidup tan pa pemberian pakan. Makanan alami dalam lambung puerulus diduga merupakan makanan alami yang didapatkan dari hasil predasi pada fase larva filosoma. Philips \& William (2009) menyatakan bahwa tahap akhir larva filosoma lobster (Decapoda, Palinuridae) bermetamorfosis menjadi puerulus (postlarva) yang merupakan fase pendek (3-4 minggu), tidak membutuhkan pakan, dan tidak melakukan aktivitas makan. Fase ini merupakan fase penghubung antara 
Tabel 1. Plankton dalam lambung lobster $(n=10)$

Table 1. Plankton in lobster stomach $(n=10)$

\begin{tabular}{|c|c|c|c|c|}
\hline $\begin{array}{l}\text { Kelompok } \\
\text { Category }\end{array}$ & $\begin{array}{l}\text { Kelas } \\
\text { Class }\end{array}$ & Ordo & $\begin{array}{l}\text { Spesies } \\
\text { Species }\end{array}$ & $\begin{array}{l}\text { Rata-rata } \pm \text { SD (ind.) } \\
\text { Average } \pm \text { SD (ind.) }\end{array}$ \\
\hline \multirow{3}{*}{ Fitoplankton } & Bacillariophyceae & Rhabdonematales & Grammatophora marina (Lyngbye) Kützing & $1 \pm 0.94$ \\
\hline & Bacillariophyceae & Naviculales & Navicula cancellata Donkin & $1 \pm 0.82$ \\
\hline & Bacillariophyceae & Fragilariales & Synedra radians Kützing & $1 \pm 1.15$ \\
\hline Zooplankton & Oligotrichea & Choreotrichida & Tintinnopsis lobiancoi Daday & $1 \pm 0.94$ \\
\hline
\end{tabular}

fase planktonik dengan fase bentik dalam siklus hidup lobster.

\section{Makanan Alami Lobster Pasir (Panulirus homarus) Fase Puerulus di Mikrohabitat}

Makanan alami di mikrohabitat juga terdiri atas dua kelompok yaitu kelompok fito plankton dan zooplankton. Kelompok fitoplankton memiliki jumlah dan spesies yang lebih banyak dibandingkan zooplankton (Tabel 2 dan 3).

Komunitas fitoplankton terdiri atas enam kelas; 26 ordo; dan 39 spesies dengan rata-rata jumlah individu sebanyak 107 individu. Spesies yang paling banyak adalah kelas Bacillariophyceae ordo Fragilariales spesies Synedra radians Kützing rata-rata sebanyak 21,2 individu. Hasil analisis data menunjukkan kelimpahan fitoplankton sebesar $65.744 \mathrm{sel} / 50 \mathrm{~mL}$, tingkat keanekaragaman tergolong tinggi $\left(\mathrm{H}^{\prime}=3,03\right)$; tingkat keseragaman jenis tinggi $(E=0,82)$; dan indeks dominansi sebesar 0,08 yang berarti tidak ada genus yang mendominasi.

Komunitas zooplankton terdiri atas 10 kelas; 10 ordo; dan 20 spesies dengan rata-rata jumlah individu sebesar 36 individu. Spesies yang paling banyak adalah Acartia clausi Giesbrancht dari kelas Hexanauplia ordo calanoida rata-rata sebanyak 16,5 individu. Hasil analisis data menunjukkan kelimpahan zooplankton sebesar $182 \mathrm{sel} / 50 \mathrm{~mL}$, tingkat keanekaragaman tergolong sedang $\left(\mathrm{H}^{\prime}=1,89\right)$, tingkat keseragaman jenis tinggi $(E=0,62)$, dan indeks dominansi sebesar 0,3 yang berarti tidak ada genus yang mendominasi.

Tidak semua makanan alami di mikrohabitat ditemukan di dalam lambung lobster pasir (Panulirus homarus) fase puerulus. Hal ini berarti bahwa lobster pasir pada fase filosoma (fase larva sebelum puerulus) melakukan aksi predasi dan pemilihan mangsa. Aktivitas pemangsaan terjadi pada fase filosoma, sedangkan pada fase puerulus lobster tidak melakukan aktivitas makan (Philips \& William, 2009). Fase puerulus tidak melakukan aktivitas makan diduga karena pengaruh hormon ekdison. Hormon ekdison berperan memicu moulting (ganti kulit) pada lobster. Terdapat empat fase moulting yaitu intermolt, premolt, moulting, dan postmolt. Aktivitas makan lobster sangat tinggi pada fase intermolt sampai premolt. Pada fase premolt akhir titer ekdison mencapai puncaknya; aktivitas makan lobster terhenti; dan lobster menjadi sangat pasif, pada fase moulting terjadi pergantian kulit dan lobster tidak melakukan aktivitas makan. Fase postmolt merupakan fase sesaat setelah moulting. Pada fase ini titer ekdison menurun drastis; lobster lebih banyak menyerap air; dan aktivitas makan mulai terjadi (Ihsan et al., 2017).

Pemilihan Grammatophora marina (Lyngbye) Kützing, Navicula cancellata Donkin, Synedra radians Kützing, dan Tintinnopsis lobiancoi sebagai makanan alami diduga disebabkan karena tiga faktor yaitu kecukupan nutrien, kemelimpahan, dan kesesuaian ukuran pakan dengan bukaan mulut larva lobster.

Molles (2016) menyatakan bahwa perbedaan rasio elemen nutrien dalam jaringan atau organisme memengaruhi jenis makanan hewan, kecepatan reproduksi, dan kecepatan dekomposisi. Larva lobster membutuhkan lipid sebagai sumber energi utama dengan jumlah dua kali lipat dibandingkan protein dan karbohidrat. Kandungan lipid, protein, dan karbohidrat dalam tubuh larva lobster berturut-turut $39,5 \mathrm{~kJ} \mathrm{~kg}^{-1}$; $23,6 \mathrm{~kJ} \mathrm{~kg}^{-1}$; dan 17,2 kJ kg-1 (Bureau et al., 2002). Asam lemak yang paling mendominasi adalah Polyunsaturated fatty acid (PUFA) sebesar 24,0\%34,1\%dari total asam lemak. Larva lobster memiliki keterbatasan kemampuan menyintesis PUFA sehingga kebutuhan asam lemak ini dipenuhi dari mangsa (Phleger et al., 2001). Diatom (kelas Bacillariophyceae) mengandung PUFA yang paling tinggi dibandingkan microalgaeyang lain, berkisar antara 23,4\%60,7\% Eicosapentaenoic acid (EPA) adalah jenis PUFA yang paling mendominasi (Valera \& Saavedra, 2016). Kandungan PUFA yang mendominasi pada diatom diduga menjadi nutrien spesifik yang memengaruhi lobster memilih diatom sebagai mangsanya. 
Tabel 2. Komunitas fitoplankton di mikrohabitat lobster

Table 2. Phytoplankton community in microhabitat of lobster

\begin{tabular}{|c|c|c|c|}
\hline $\begin{array}{l}\text { Kelas } \\
\text { Class }\end{array}$ & Ordo & $\begin{array}{l}\text { Spesies } \\
\text { Species }\end{array}$ & $\begin{array}{l}\text { Rata-rata } \pm \text { SD (ind.) } \\
\text { Average } \pm \text { SD (ind.) }\end{array}$ \\
\hline Bacillariophyceae & Bacillariales & Bacillaria paradoxa J.F.Gmelin. nom. illeg. & $2.7 \pm 6.5$ \\
\hline Bacillariophyceae & Chaetocerotales & Bacteriastrum hyalinum Lauder & $2.8 \pm 4.0$ \\
\hline Bacillariophyceae & Rhabdonematales & Grammatophora marina (Lyngbye) Kützing & $7.3 \pm 10.2$ \\
\hline Bacillariophyceae & Licmophorales & Licmophora abbreviate C. Agardh & $2.5 \pm 5.6$ \\
\hline Bacillariophyceae & Naviculales & Naviculacancellata Donkin & $0.8 \pm 0.8$ \\
\hline Bacillariophyceae & Bacillariales & Nitzschia sigma (Kützing) W. Smith & $0.2 \pm 0.4$ \\
\hline Bacillariophyceae & Naviculales & Pleurosigma normanii Ralfs & $1.5 \pm 2.3$ \\
\hline Bacillariophyceae & Naviculales & Gyrosigma strigilis (W. Smith) J.W. Griffin \& Henfrey & $0.2 \pm 0.4$ \\
\hline Bacillariophyceae & Rhabdonematales & Rhabdonema adriaticum Kützing & $3.3 \pm 8.2$ \\
\hline Bacillariophyceae & Surirellales & Surirella cuneata A. Schmidt & $0.2 \pm 0.4$ \\
\hline Bacillariophyceae & Fragilariales & Synedra formosa Hantzsch & $0.3 \pm 0.8$ \\
\hline Bacillariophyceae & Thalassionematales & Thalassionema frauenfeldii (Grunow) Tempère $\&$ Peragallo & $0.8 \pm 1.3$ \\
\hline Bacillariophyceae & Cymbellales & Cymbella kappii (Cholnoky) Cholnoky & $1 \pm 2.4$ \\
\hline Bacillariophyceae & Fragilariales & Synedra radians Kützing & $21.2 \pm 43.7$ \\
\hline Coscinodiscophyceae & Coscinodiscales & Coscinodiscus granii L.F. Gough & $1.5 \pm 2$ \\
\hline Coscinodiscophyceae & Melosirales & Melosira sulcata (Ehrenberg) Kützing & $4.5 \pm 6.4$ \\
\hline Coscinodiscophyceae & Rhizosoleniales & Rhizosolenia fragillima H.H. Gran & $1 \pm 2.4$ \\
\hline Coscinodiscophyceae & Rhizosoleniales & Rhizosolenia styliformis T. Brightwell & $0.3 \pm 0.5$ \\
\hline Coscinodiscophyceae & Coscinodiscales & Aulacodiscus voluta-coeli Brun & $1.5 \pm 1.4$ \\
\hline Coscinodiscophyceae & Melosirales & Hyalodiscus stelliger J.W. Bailey & $2.8 \pm 5.6$ \\
\hline Coscinodiscophyceae & Triceratiales & Triceratium favus Ehrenberg & $1.3 \pm 1.6$ \\
\hline Cyanophyceae & Oscillatoriales & Trichodesmium erythraeum Ehrenberg ex Gomont & $14.6 \pm 28.2$ \\
\hline Dinophyceae & Dinophysiales & Dinophysis caudate Saville-Kent & $0.2 \pm 0.4$ \\
\hline Dinophyceae & Peridiniales & Protoperidinium ovum (Schiller) Balech & $2.8 \pm 2.9$ \\
\hline Dinophyceae & Peridiniales & Protoperidinium oceanicum (Vanhöffen) Balech & $0.7 \pm 1.2$ \\
\hline Mediophyceae & Biddulphiales & Biddulphia mobiliensis (J.W. Bailey) Grunow & $1.3 \pm 1.2$ \\
\hline Mediophyceae & Chaetocerotales & Chaetoceros affinis Lauder & $2 \pm 3.6$ \\
\hline Mediophyceae & Chaetocerotales & Chaetoceros atlanticus Cleve & $0.3 \pm 0.8$ \\
\hline Mediophyceae & Chaetocerotales & Chaetoceros curvisetus Cleve & $5.8 \pm 11.9$ \\
\hline Mediophyceae & Chaetocerotales & Chaetoceros decipiens Cleve & $1.7 \pm 2.7$ \\
\hline Mediophyceae & Chaetocerotales & Chaetoceros didymus Ehrenberg & $5 \pm 7.8$ \\
\hline Mediophyceae & Chaetocerotales & Chaetoceros leave G. Leuduger-Fortmorel & $0.7 \pm 1.0$ \\
\hline Mediophyceae & Chaetocerotales & Chaetoceros Iorenzianus Grunow & $4 \pm 6.4$ \\
\hline Mediophyceae & Toxariales & Climacosphenia moniligera Ehrenberg & $2 \pm 4.9$ \\
\hline Mediophyceae & Thassiosirales & Skeletonema costatum (Greville) Cleve & $1 \pm 2.4$ \\
\hline Mediophyceae & Eupodiscales & Auliscus caelatus Bailey & $1.3 \pm 2$ \\
\hline Mediophyceae & Biddulphiales & Biddulphia obtuse (Kützing) Ralfs & $2.7 \pm 3.1$ \\
\hline Mediophyceae & Anaulales & Terpsinoë Americana (Bailey) Grunow & $0.3 \pm 0.8$ \\
\hline Ulvophyceae & Chladoporales & Cladophora sp. & $2.5 \pm 4.7$ \\
\hline \multicolumn{3}{|r|}{ Total } & 107 \\
\hline
\end{tabular}

Faktor kemelimpahan/ketersediaan makanan juga dapat menentukan preferensi makan hewan (Molles, 2016). Houki et al. (2018) menyatakan Manila clamp Ruditapes phillipinarum memangsa diatom bentik dan diatom planktonik karena ketersediaannya yang melimpah meskipun diatom bentik memiliki frustula. Pemangsaan pada satu sumber makanan oleh copepoda menurun ketika kemelimpahan dan keanekaragaman makanan meningkat (Wickmans et al., 2007). Lobster memangsa Grammatophora marina
(Lyngbye) Kützing dan Synedra radians Kützing seiring kemelimpahannya yang paling tinggi di mikrohabitat.

Kesesuaian ukuran mangsa dengan pemangsajuga menjadi faktor pemilihan mangsa oleh predator. Trijoko \& Pasaribu (2004) menyatakan bukaan mulut larva lobster sebesar $114 \mu \mathrm{m}$, sehingga mangsa yang ukuran tubuhnya lebih besar dibandingkan bukaan mulut tidak akan dipilih oleh larva lobster. Grammatophora marina (Lyngbye) Kützing, Navicula cancellata Donkin, dan Synedra radians Kützing 
Tabel 3. Komunitas zooplankton di mikrohabitat lobster

Table 3. Zooplankton community in microhabitat of lobster

\begin{tabular}{|c|c|c|c|}
\hline $\begin{array}{l}\text { Kelas } \\
\text { Class }\end{array}$ & Ordo & $\begin{array}{l}\text { Spesies } \\
\text { Species }\end{array}$ & $\begin{array}{c}\text { Rata-rata } \pm \text { SD (ind.) } \\
\text { Average } \pm \text { SD (ind.) }\end{array}$ \\
\hline Anthozoa & Spirularia & Cerianthus membranaceus Gmelin (planula) & $0.5 \pm 1.2$ \\
\hline Bivalvia & Ostreida & Pinctada maxima Jameson & $0.5 \pm 0.8$ \\
\hline Globothalamea & Rotaliida & Globorotalia menardii Jones and Brady & $0.3 \pm 0.5$ \\
\hline Hexanauplia & Calanoida & Acartia clausi Giesbrancht & $16.5 \pm 15.5$ \\
\hline Hexanauplia & Calanoida & Calanus sinicus Brodsky & $8.8 \pm 11.8$ \\
\hline Hexanauplia & Harpacticoida & Tigriopus japonicus Mori & $0.3 \pm 0.8$ \\
\hline Hydrozoa & Anthoathecata & Turritopsis nutricula McCrady & $0.3 \pm 0.8$ \\
\hline Malacostraca & Decapoda & Penaeus semisulcatus De Haan & $0.3 \pm 0.5$ \\
\hline Oligotrichea & Choreotrichida & Tintinnopsis lobiancoi Daday & $1.3 \pm 1.0$ \\
\hline Oligotrichea & Choreotrichida & Amphorellopsis acuta Schmidt & $0.3 \pm 0.8$ \\
\hline Oligotrichea & Choreotrichida & Amphorides amphora Claparede and Lachmann & $1.2 \pm 1.5$ \\
\hline Oligotrichea & Choreotrichida & Codonellopsis ostenfeldi Schmidt & $0.5 \pm 0.5$ \\
\hline Oligotrichea & Choreotrichida & Eutintinnus fraknoii Daday & $0.3 \pm 0.8$ \\
\hline Oligotrichea & Choreotrichida & Leprotintinnus pellucidus Cleve & $0.8 \pm 1.6$ \\
\hline Oligotrichea & Choreotrichida & Leprotintinus nordqvisti Brandt & $1.3 \pm 2.2$ \\
\hline Oligotrichea & Choreotrichida & Tintinnopsis aperta Brandt & $0.5 \pm 0.8$ \\
\hline Oligotrichea & Choreotrichida & Tintinnopsis schotti Brandt & $0.3 \pm 0.8$ \\
\hline Polychaeta & Canalipalpata (Infraclass) & Sabellaria alveolata Linnaeus & $0.3 \pm 0.5$ \\
\hline Thaliace & Salpida & Cyclosalpa pinnata Forskal & $1.5 \pm 2.3$ \\
\hline Litostomatea & Haptorida & Didinium nasutum Muller & $0.2 \pm 0.4$ \\
\hline
\end{tabular}

termasuk dalam kelompok diatom dengan ukuran diameter tubuh berkisar 2-500 $\mu \mathrm{m}$ (Tomas, 1997). Sedangkan Tintinnopsis lobiancoi Daday termasuk dalam kelompok protozooplankton dengan diameter tubuh 34-62 $\mu \mathrm{m}$ (Lenz, 2000; Yousif et al., 2011). Diameter tubuh Synedra radians Kützing yang ditemukan berkisar 9,85-10,82 $\mu \mathrm{m}$.

Makanan alami berupa zooplankton di mikrohabitat lobster berbeda dengan makanan alami yang ditemukan di Teluk Wedi Ombo, Gunung Kidul, Yogyakarta. Zooplankton di Teluk Awang terdiri atas 10 kelas dan 10 ordo, sedangkan di Teluk Wedi Ombo terdiri atas delapan subkelas dan tujuh ordo. Beberapa ordo yang ditemukan di Teluk Awang juga ditemukan di Teluk Wedi Ombo seperti Acartia yang dijumpai pada kedua perairan. Akan tetapi, terdapat beberapa spesies yang tidak ditemukan di Teluk Wedi Ombo seperti Tintinopsis hanya dijumpai di Teluk Awang. Adanya kesamaan dan perbedaan kondisi perairan khususnya faktor nutrisi diduga menjadi faktor yang menyebabkan variasi distribusi plankton di laut lepas (Hartoko, 2013). Jenis plankton yang dimangsa oleh larva lobster di Teluk Wedi Ombo belum bisa ditentukan karena belum dilakukan penelitian tentang analisis lambung lobster.
Tintinopsis lobiancoi termasuk ke dalam protozoa kingdom Alveolata, filum Ciliophora, subfilum Intramacronucleata, Kelas Spirotrichea, Subkelas Choretrichia, Ordo Tinitinnida, famili codonellidae. Struktur tubuh tintinid dari genus tintinopsis (family codonellidae) memiliki gumpalan-gumpalan yang bentuknya bervariasi pada bagian oral, leher, dan basal (Yousif et al., 2011). Genus Tintinopsis terdistribusi pada daerah neritik (neritic genera) dengan kedalaman sekitar $200 \mathrm{~m}$ (Dolan \& Pierce, 2012). Espinoza et al. (2015) menyatakan bahwa larva lobster masih bisa ditemukan pada kedalaman $100 \mathrm{~m}$. Pada waktu pemijahan, induk lobster melakukan migrasi ke laut dalam mencari lokasi yang sesuai untuk melepaskan telur yang akan berkembang menjadi larva (Philips, 2006). Hal ini memungkinkan larva lobster tersebar pada berbagai kedalaman dan dapat ditemukan pada kedalaman yang sama dengan kedalaman $200 \mathrm{~m}$, tempat terdistribusinya tintinopsis.

Indeks keanekaragaman $\left(\mathrm{H}^{\prime}\right)$ fitoplankton pada penelitian ini sebesar 3,03; dan tergolong tingkat keanekaragaman yang tinggi (Magurran, 2004; Fachrul, 2007). Keanekaragaman yang tinggi memiliki dua arti yaitu pertama kandungan nutrien yang menunjang kehidupan fitoplankton tersedia dengan baik dan 
kedua komunitas fitoplankton di Teluk Awang memiliki tingkat similaritas yang rendah dan tidak ada satu atau dua takson yang mendominasi perairan (Hartoko, 2013).

Indeks keanekaragaman zooplankton pada penelitian ini sebesar 1,88; yang tergolong dalam kategori sedang (Magurran, 2004; Fachrul, 2007). Hal ini diduga karena adanya aktivitas migrasi harian zooplankton. Distribusi zooplankton dipengaruhi oleh tiga faktor yaitu kedalaman air, status tropik, dan suhu. Zooplankton melakukan migrasi harian berupa naik ke permukaan pada menjelang senja dan turun ke dasar menjelang fajar. Migrasi vertikal musiman dilakukan oleh banyak anggota copepod genus Calanus dari kedalaman 0-1.000 m (Lenz, 2000). Aktivitas migrasi harian zooplankton tidak diteliti pada penelitian ini, diperlukan kajian lebih lanjut tentang aktivitas ini untuk memastikan efeknya terhadap tingkat keanekaragaman zooplankton.

\section{KESIMPULAN}

Makanan alami dalam lambung lobster pasir (Panulirus homarus) fase puerulus terdiri atas fitoplankton kelas bacillario phyceae (Grammatophora marina, Navicula cancellata, dan Synedra radians) dan zooplankton kelas oligotricheae (Tintinnopsis lobiancoi). Struktur komunitas makanan alami di mikrohabitat terdiri atas fitoplankton dengan enam kelas; 26 ordo; dan 39 spesies, sedangkan zooplankton terdiri atas 10 kelas; 10 ordo; dan 20 spesies.

\section{UCAPAN TERIMA KASIH}

Ucapan terima kasih disampaikan kepada Rektor UIN Mataram yang telah memberikan dana penelitian yang bersumber dari DIPA UIN Mataram tahun anggaran 2018 dan nelayan di Teluk Awang yang telah membantu pengambilan sampel.

\section{DAFTAR ACUAN}

Bahrawi, S., Priyambodo, B., \& Jones, C. (2014). Census of the lobster seed fishery of Lombok. Proceedings of the International Lobster Aquaculture Symposium. Lombok, Indonesia: ACIAR, p. 12-19.

Berger, W.H. \& Parker, F.L. (1970). Diversity of planktonic foraminifera in deep-sea sediments. Science, 168, 1345-1347 DOI: http://dx.doi.org/10.1126/science.168.3937.1345.

Bureau, D.P., Kaushik, S.J., \& Cho, C.Y. (2002). Bioenergetics. In Halver, J.E. \& Hardy, R.W. (Eds.). San Diego: Academic Press. Fish nutrition, p. 1-59.

Conel, S.C., O'Rorke, R., Jeffs, A.G., \& Lavery, S.D. (2014). DNA identification of the phyllosoma diet of Jasus edwardsii and Scyllarus sp. New Zealand
Journal of Marine and Freshwater Research, 48(3), 416-429. DOl: http://dx.doi.org/10.1080/ 00288330.2014 .914042$.

Dolan, J.R. \& Pierce, R.W. (2012). Diversity and distribution of tintinnids. In Dolan, J.R., Montagnes, D.J.S., Agatha, S., Coats, D.W., \& Stoecker, D. (Eds.). The biology and ecology of tintinnid ciliates: Models for marine plankton. First Edition. USA: John Wiley \& Sons, Ltd., 296 pp.

Espinoza, E., Masaquisa, S., \& Moreno, J. (2015). Settlement habitat and seasonal relative abundance of spiny lobster Panulirus sp. larvae and accompanying fauna in the Galapagos marine serve. In Galapagos Report 2013-2014. GNPD, GCREG, CDF and GC. Galapagos: Puerto Ayora, p.125-129.

Fachrul, M.F. (2007). Metode sampling bioekologi. Jakarta: Bumi Aksara, $198 \mathrm{hlm}$.

Hartoko, A. (2013). Oceanographic Characters and Plankton Resources of Indonesia. Yogyakarta: Graha Ilmu, $159 \mathrm{hlm}$.

Hasanah, A.N., Rukminasari, N., \& Sitepu, F.G. (2014). Perbandingan kelimpahan dan struktur komunitas zooplankton di Pulau Kodingareng dan Lanyukang Kota Makasar. Torani (Jurnal Ilmu Kelautan dan Perikanan), 24(1), 1-14.

Houki, S., Kawamura, T., Ogawa, N., \& Watanbe, Y. (2018). Efficient crushing of hard benthic diatoms in the gut of the Manila Clamp Ruditaphes philippinarum - experimental and observational evidence. Journal of Experimental MarineBiology and Ecology, 505, 35-44. DOI: http://doi.org/10.1016/ j.jembe.2018.04.007.

Ihsan, M., Istriyati, \& Muliasari, H. (2017). Morfologi dan histologi hepatopankreas (midgut gland) lobster hijau pasir (Panulirus homarus). Bio Wallacea, Jurnal Ilmiah IImu Biologi, 3(3), 115-118.

Ihsan, M., Kalih, L.A.T.W.S., \& Ilyas, M.A. (2016). Identifikasi makanan alami dalam lambung lobster fase juvenil untuk menopang budidaya lobster yang berkelanjutan di Pulau Lombok. BioWallacea, Jurnal IImiah Ilmu Biologi, 2(2), 174-177.

Ihsan, M., Trijoko, \& Widjayanti, N. (2017). Titer ekdison lobster hijau pasir (Panulirus homarus L.) pada fase premolting akhir. Scripta Biologica, 4(4), 257-261. DOI: 10.20884/1.sb.2017.4.4.643.

Jeffs, A. (2007). Revealing the natural diet of the phyllosoma larvae of spiny lobster. Bulletin Fisheries Research Agency, 20, 9-13.

Jones, D.A., Yule, A.B., \& Holland, D.L. (1997). Larval nutrition. In Louis D'Abramo (Ed.). Advances in world aquaculture crustacean nutrition. USA: The World Aquaculture Society, 6, 353-389. 
Kamariah \& Tarunamulia. (2016). Struktur komunitas fitoplankton di tambak Silvofishery Kabupaten Subang, Jawa Barat. Dalam Prosiding Forum Inovasi Teknologi Akuakultur, hlm. 263-269.

Kuwata, A. \& Jewson, D.H. (2015). Ecology and evolution of marine diatoms and parmales. In Ohtsuka, S., Suzaki, T., Horiguchi, T., Suzuki, N., \& Not, F (Eds.). Marine protists diversity and dynamics. Japan: Springer Japan, p. 251-276. DOI: 10.1007/9784-431-55130-0.

Lenz, J. (2000). Introduction. In Harris, R.P., Weibe, P.H., Lenz, J., Skjodal, H.R., \& Huntley, M. (Eds.). ICES Zooplankton Methodology Manual. London: Academic Press, p. 1-32.

Magurran, A.E. (2004). Measuring biological diversity. UK: Blackwell Publishing, 248 pp.

Molles, M.C.Jr. (2016). Ecology: Concepts and applications. Seventh editions. New York: McGraw-Hill Education, $567 \mathrm{pp}$.

O'Rorke, R., Lavery, S.D., Wang, M., Nodder, S.D., \& Jeffs, A.G. (2013). Determining the diet of larvae of the red rock lobster (Jasus edwardsii) using highthroughput DNA sequencing techniques. Marine Biology, 161, 551-563. DOI: 10.1007/s00227-0132357-7.

Philips, B.F. (2006). Lobster: Biology, management, aquaculture, and fisheries. Singapore: Blackwell Publishing Ltd., $536 \mathrm{pp}$.

Philips, B.F. \& William, P.S. (2009). Spiny lobster development: Where does successful metamorphosis to the puerulus occur?: A review. Rev. Fish Biol. Fisheries, 19, 193-215. DOI: 10.1007/s11160-0089099-5.

Phleger, C.F., Nelson, M.M., Mooney, B.D., Nicholas, P.D., Ritar, A.J., Smith, G.G., Hart, P.R., \& Jeffs, A.G. (2001). Lipid and nutrition of the southern rock lobster, Jasus edwardsii, from hatch to puerulus. Marineand Freshwater Research, 52, 14751486. DOI: 10.1071/MF01071.

Putri, S.I.P. \& Sari, S.H.J. (2015). Struktur komunitas fitoplankton dan kaitannya dengan ketersediaan zat haradan parameter kualitas air lainnya di perairan timur Surabaya. Depik, 4(2), 79-86. DOI: http://dx.doi.org/10.13170/depik.4.2.2455.

Smith, G., Salmon, M., Kenway, M., \& Hall, M. (2009). Description of the larval morphology of captive rared Panulirus ornatus spiny lobsters, benchmarked against wild-caught specimens. Aquaculture, 295, 76-88. DOI: 10.1016/ j.aquaculture.2009.06.030.

Suzuki, N., Murakami, K., Takeyama, H., \& Chow, S. (2006). Molecular attempt to identify prey organism of lobster phyllosoma larvae. Fisheries Sci., 72, 342-349.

Tomas, C.R. (1997). Identifying Marine Phytoplankton. UK: Academic Press, $858 \mathrm{pp}$.

Trijoko \& Pasaribu, D.U.W. (2004). Inventarisasi zooplankton untuk pakan alami larva udang karang (Panulirus homarus L.) di Teluk Wedi Ombo, Gunung Kidul, Yogyakarta. Jurnal Perikanan UGM (GMU J. Fish. Sci. ), 6(1), 24-33.

Tsukazaki, C., Ishii, K.I., Saito, R., Matsuno, K., Yamaguchi, A., \& Imai, I. (2013). Distribution of viable diatom resting stage cells in bottom sediments of the eastern Bering Sea Shelf. Deep-Sea Research II, 94, 22-30. DOI: http://doi.org/10.1016/ j.dsr2.2013.03.020.

Valera, S.J. \& Saavedra, M.S. (2016). Growth and fatty acid profiles of microalgae species isolated from the Baja California Peninsula, M exico. Latin American Journal of Aquatic Research, 44(4), 689-702. DOI: 10.3856/vol44-issue4-fulltext-4.

Wickmans, M., Chepurnov, V.A., Vanreusel, A., \& Torch, M.D. (2007). Effect of food diversity on diatom selections by harpacticoid copepods. Journal of Experimental Marine Biology and Ecology, 345, 119-128. DOI: http://doi.org/10.1016/ j.jembe.2007.02.0072.

Yamaji, I. (1976). Illustration of marine plankton. Japan: Hoikush Publishing Co. Ltd., 537 pp.

Yousif, F.A., Skryabin, V., Gubanova, A., Khvorov, S., \& Prusova, I. (2011). Marine practical zooplankton guide for the Northwestern Arabian Gulf. Kuwait: Kuwait Institute for Scientific Research Publisher, 1, 196 pp. 